\title{
International information seeking behaviour of South African exporters
}

\author{
W. Viviers \\ School of Economics, Risk Management and International Trade \\ Potchefstroom University for Christian Higher Education \\ South Africa \\ eknwv@puknet.puk.ac.za
}

\author{
J.L. Calof \\ University of Ottawa \\ Canada
}

\section{Contents}

1. Introduction

2. Why would South African exporting be different?

3. Methodology

4. Results

5. Conclusion

6. References

\section{Introduction}

While there are many requirements for making successful decisions, the raw material is information. Nowhere is this more evident than in the international arena. As Czinkota (1991:86) wrote: 'Information is even more important in the international setting, where entirely new parameters and environments are encountered.' Unfortunately, in spite of the growing importance of international trade, little knowledge exists about how firms gather information outside of their home country. The recognition of this lack of research has lead to a special call for papers by International Marketing Review in 2001, looking at this issue. There are a plethora of studies that look at how domestic firms gather information (e.g. Prescott and Bhardwaj, 1995, looked at the type of information collected by American firms). However, with the exception of a handful of studies (e.g. Bodur and Cavusgal 1985; Calof 1997; Hart, Webb and Jones 1994; Souchon and Diamantopoulos 1999; Mohamad, Zafar and Honeycutt 2001) it is not known whether these findings apply in an international context. More important for this study, research to date has focused on developed countries (Canada, United States and the United Kingdom) and not on an emerging or an economy in transition, such as the South African one.

Why the need for an investigation at international information collection? The growing importance of international business for many countries requires that we better understand 
how information seeking should be conducted for international efforts. Unfortunately, as Czinkota found in his literature review (1991), few studies have studied this issue.

Furthermore, there is ample evidence that there are differences in collection efforts for domestic versus international markets. As Hoetker (1996:4) pointed out, 'the key to making these modifications is understanding the special challenges presented by the international setting'. Unfortunately, many managers do not recognize these differences and are remiss in their international collection efforts. Furthermore, there is growing evidence that managers are careless in their international information collection efforts. A study by Calof (1993) found that even when it comes to something as important as the decision to open a foreign branch, few companies did more than discuss it with a few friends. Only 35\% conducted a formal study, $18 \%$ considered alternatives and only $49 \%$ of the time did the decision maker even discuss the decision with anyone outside the organization. This differs from actions than one would normally see in a local situation.

As yet, a small number of authors have indicated the importance of having reliable international information:

- Ricks (1993) noted that 'most international blunders could have been avoided if the firm and its management had obtained adequate information about the business environment'.

- Czinkota and Ricks (1991) found that exporters believe increased market information gathering and information on business practices were key variables in improving their foreign trade performance.

- Johanson and Vahlne (1978) concluded that a lack of foreign environmental knowledge is an important obstacle to the internationalization of the firm.

The purpose of this research was to examine how firms dealing with market opportunities outside their own country collect information. Specifically:

- What information is most important to exporters?

- What sources of information are important to exporters?

- What problems do South African exporters encounter when trying to access information?

To answer these questions, the results of the research that examined how South African exporters collect information for international markets are discussed.

\section{Why would South African exporting be different?}

The first part of the introduction discussed why the topic itself is important. However, why focus the investigation on South Africa? Several studies have looked at various elements of the export decision-making process, but virtually all these studies have been within North America and Europe. Little is known about the applicability of these theories within a developing market context. Further, within South Africa there are several cultural, legal, political and economic circumstances that may affect both the desire and capability to obtain international information:

a) Sanctions: The 1980s saw growing pressure from abroad for political change to be effected in South Africa, and a variety of economic sanctions were imposed by a number of countries (e.g. USA, Canada and the Scandinavian countries) in an attempt to cause the desired changes. The inability to export may have created an entire generation with limited interest in exploring even the idea of foreign markets. Now that the sanctions have been 
removed, South Africa has a world of new possible export markets and is part of the open world economy. This is a situation rarely seen in the international literature.

b) Exchange control restrictions: Owing to concerns regarding exchange rate fluctuations and the loss of South African capital, the South African Reserve Bank in 1961 instituted rules and regulations designed to limit capital flight. For example, South African firms could only open up foreign subsidiaries if South African assets were not pledged or encumbered in any way; profitability within one year must have been assured; and only a limited amount of South African currency must have been used. These were a few of the restrictions on opening up subsidiaries. By limiting a firm's ability to expand within international markets using foreign direct investment modes (sales branches, joint ventures and wholly owned production subsidiaries), the South African government was negatively affecting one of the variables associated with the normal expansionary path of internationalization. This could have acted as a further damper on the desire to obtain foreign information in the years before 1994. Although the political situation and exchange controls have changed dramatically since 1994, the psychological effects of exchange control restrictions and sanctions may have long-term effects.

c) Inward looking culture: South African firms have a general 'inward' focus - a psychological aversion to exporting. This is due to a number of barriers, both structural and psychological in competing on international markets (Leibold 1984). Securing international information is predicated on having an outward-looking view. It is possible that the inwardlooking view could negatively impact the information gathering process.

Finally, South Africa is also the subject of this study as little is known about South Africa's international information seeking behaviour.

\section{Methodology}

On questioning the Pretoria Metropolitan Council (South Africa) about the information required by their members, it sent out a survey to their members in 1999 asking questions related to types of information required, present sources of information, difficulties accessing and using information, and preferred ways of receiving information. The authors of this article were presented with the data set for analysis. All questions used in this study were developed by the Pretoria Metropolitan Council and not by the authors of this study. However, the questions themselves are very similar to those found in published results of export information studies.

Of the Council firms approached for this study, 150 responded to the questionnaire and 114 indicated that they had some exporting experience (providing a date when exporting first commenced). Three of these firms had over 200 employees [South Africa's definition of large firms (Department of Trade and Industry 1995)]. For the purposes of this study, only responses from small and medium-sized firms were used. The responses from these firms form the basis for this article. Respondent firms came from a mix of industries including manufacturing, agriculture, and services; high technology and low technology. Responding firms had on average 54 employees with $88 \%$ having fewer than 100 employees. Total export turnover averaged 14 million South African rand (approximately \$1,7 million USD conversion rate as in August 2001: USD $1=$ ZAR 8,24). Average export sales per employee was USD 24266 with responding firms having on average 9,5 years of export experience. These respondent characteristics compare favourably to those from past South African studies (the Calof and Viviers 1995 internationalization study had almost identical characteristics). 


\section{Results}

\subsection{Types of international information gathered}

Two different sections of the questions asked firms about the type of information that was of most interest. The first presented 40 different types of information and asked respondents to indicate the importance of each using a Likhert scale of $0=$ no interest and $3=$ high interest. These 40 different types of information were grouped into 10 broad categories: potential business partners, trade-related organizations, business opportunities, statistics, market access conditions, distribution, sales promotion, market intelligence, global information on foreign markets and import information. Respondents were then asked to rank the relative importance of each of these categories, with 1 being the most important, 2 second most important and so forth. Tables 1 and 2 present the rankings for the responses while Table 3 presents the average results by information category.

Respondents indicated that information related to potential buyers was most important $(2,7)$ followed by price quotations and trends $(2,3)$. These market demand type issues were then followed by information needs related to market access, such as tariff information and trade regulations. These more general information needs have been seen as dominant in other international information studies (Calof 1997) and reflect the desire to better understand the foreign regulatory environment. They may also reflect South Africa's unique situation in terms of regulatory-related (sanctions) problems and lack of international competitiveness.

Table 1 Information needs of South African exporters: order of category priority

\begin{tabular}{|l|c|}
\hline Information type & $\begin{array}{c}\text { Rank } \\
\text { (average) }\end{array}$ \\
\hline Market access conditions & $1(3,1)$ \\
\hline Market intelligence & $2(3,5)$ \\
\hline Business opportunities & $3(3,6)$ \\
\hline Distribution & $4(3,9)$ \\
\hline Potential business partners & $5(4,9)$ \\
\hline Sales promotion & $6(5,2)$ \\
\hline Global information on foreign markets & $7(5,3)$ \\
\hline Trade-related organizations & $8(8,5)$ \\
\hline Statistics & $8(8,5)$ \\
\hline Import of production inputs & $10(9,8)$ \\
\hline
\end{tabular}

Table 2 Information needs of South African exporters in rank order

\begin{tabular}{|l|c|}
\hline Information type & Average \\
\hline Potential buyers & 2,7 \\
\hline Price quotations and trends & 2,4 \\
\hline Products and services offers and demands & 2,3 \\
\hline Trade regulations and foreign access controls & 2,3 \\
\hline Tariffs & 2,3 \\
\hline Distribution channels & 2,3 \\
\hline
\end{tabular}




\begin{tabular}{|c|c|}
\hline Transport facilities and procedures & 2,3 \\
\hline Trade practices & 2,3 \\
\hline Information on demand & 2,3 \\
\hline Information on competitors & 2,3 \\
\hline Technical standards & 2,2 \\
\hline Information on foreign suppliers & 2,2 \\
\hline Credit information on foreign buyers & 2,1 \\
\hline Potential suppliers & 2,1 \\
\hline Import procedures & 2,1 \\
\hline Packaging and labelling rules & 2,1 \\
\hline Technological trends & 2,1 \\
\hline Trade policy and foreign trade trend & 2,1 \\
\hline Practical hints for businessmen & 2,1 \\
\hline Quality certifications systems & 2,0 \\
\hline Trade agreements and relevant implications & 2,0 \\
\hline National and international export/import statistics & 1,9 \\
\hline Non-tariff barriers & 1,9 \\
\hline Packaging requirements and design & 1,9 \\
\hline Fairs and exhibitions & 1,9 \\
\hline Tender boards, procurement agencies & 1,8 \\
\hline Free trade zones & 1,8 \\
\hline Regulations for sales and agency contracts & 1,8 \\
\hline Advertising & 1,8 \\
\hline International tender notices & 1,7 \\
\hline Political and economic environment & 1,7 \\
\hline $\begin{array}{l}\text { Official trade promotion organizations and other public sector } \\
\text { organizations }\end{array}$ & 1,6 \\
\hline Private sector organizations & 1,6 \\
\hline Safety, sanitary regulations & 1,5 \\
\hline Investment/joint venture with foreign companies & 1,4 \\
\hline Development projects & 1,4 \\
\hline Environment and consumer protection regulations & 1,4 \\
\hline National and international production statistics & 1,3 \\
\hline National and international socio-economic indicators & 1,3 \\
\hline Fashion trends & 1,3 \\
\hline Warehousing facilities & 1,2 \\
\hline
\end{tabular}

Table 3 Information needs of South African exporters ordered by information category

\begin{tabular}{|l|c|}
\hline Information type & Average \\
\hline Potential business partners & \\
\hline Potential buyers & 2,7 \\
\hline Credit information on foreign buyers or potential suppliers & 2,1 \\
\hline &
\end{tabular}




\begin{tabular}{|l|c|}
\hline Tender boards, procurement agencies & 1,8 \\
\hline Trade-related organizations & \\
\hline $\begin{array}{l}\text { Official trade promotion organizations and other public sector } \\
\text { organizations }\end{array}$ & 1,6 \\
\hline Private sector organizations & 1,6 \\
\hline Business opportunities & 2,3 \\
\hline Products and services offers and demands & 1,7 \\
\hline International tender notices & 1,4 \\
\hline $\begin{array}{l}\text { Investment/joint venture with foreign companies and Development } \\
\text { projects }\end{array}$ & \\
\hline Statistics & 1,9 \\
\hline National and international export/import statistics & 1,3 \\
\hline $\begin{array}{l}\text { National and international production statistics/socio-economic } \\
\text { indicators }\end{array}$ & \\
\hline Market access conditions & 2,3 \\
\hline Trade regulations and foreign access controls & 2,1 \\
\hline Import procedures & 2,3 \\
\hline Tariffs & 1,9 \\
\hline Non-tariff barriers & 2,2 \\
\hline Technical standards & 2,0 \\
\hline Quality certifications systems & 1,5 \\
\hline Safety, sanitary regulations & 2,1 \\
\hline Packaging and labeling rules & 1,4 \\
\hline Environment and consumer protection regulations & 2,3 \\
\hline Distribution & 2,3 \\
\hline Distribution channels & 2,3 \\
\hline Transport facilities and procedures & 1,8 \\
\hline Free trade zones & 1,2 \\
\hline Warehousing facilities & 2,3 \\
\hline Regulations for sales and agency contracts & 1,9 \\
\hline Trade practices & 1,8 \\
\hline Sales promotion & 1,9 \\
\hline Packaging requirements and design & 2,3 \\
\hline Advertising & \\
\hline Fairs and exhibition & 2,3 \\
\hline Market intelligence & \\
\hline Information on demand & \\
\hline Information on competitors & \\
\hline Information on foreign suppliers & \\
\hline Price quotations and trends & \\
\hline Technological trends & \\
\hline Fashion trends & Global information on foreign markets \\
\hline & \\
\hline
\end{tabular}




\begin{tabular}{|l|c|} 
Political and economic environment & 1,7 \\
\hline Trade policy and foreign trade trend & 2,1 \\
\hline Trade agreements and relevant implications & 2,0 \\
\hline Practical hints for businessmen & 2,1 \\
\hline
\end{tabular}

These information priorities are different from those seen in studies on domestic information gathering activities. For example, dominant in the list of international information needs was buyer information and the regulatory environment in foreign countries. In contrast, Prescott and Bhardwaj (1995) in their study on information seeking behaviours of largely US companies found these to be ad hoc. Far more important for them were general industry trends and potential competitors. While information on competitors figured prominently in this study $(2,3)$ it was not as dominant as in the Prescott study. These differences may reflect the need for a different type of information when competing internationally.

\subsection{Sources approached for international information}

Where do South African firms get their international information? There are a variety of information sources available when it comes to obtaining international information.

Numerous South African government departments and agencies (such as the Department of Trade and Industry, the Department of Foreign Affairs and the Chambers of Commerce) offer export assistance. In addition, countless provincial agencies also have export assistance programmes as do municipal agencies, consulting firms, universities, banks, and so forth. To better understand where exporters find international information, respondents were presented with a list of 14 information sources and asked to identify the relative importance of each information source, using a four-point scale $(0=$ not used, to $3=$ highly used $)$. The average responses for these sets of questions are presented in Table 4.

Table 4 Information source importance for South African exporters

\begin{tabular}{|l|c|}
\hline Information source & Average \\
\hline Publications & 2,3 \\
\hline Trade partners, customers, suppliers & 2,2 \\
\hline Trade fairs and other events & 2,0 \\
\hline Databases & 2,0 \\
\hline Documentation service of your enterprise & 1,9 \\
\hline Internal knowledge (staff) & 1,8 \\
\hline Information specialists & 1,7 \\
\hline Trade-related organizations in your country & 1,7 \\
\hline Foreign trade representatives in your country & 1,6 \\
\hline International organizations & 1,6 \\
\hline Trade promotion organizations abroad & 1,5 \\
\hline Market research institutes & 1,4 \\
\hline Trade representatives of your country abroad & 1,4 \\
\hline Documentation centers (e.g. national library) in your country & 1,3 \\
\hline
\end{tabular}

Scale: 1 = Not important; 3 = Very important

The dominant source of information was publications $(2,3)$ followed by trade partners, customers and suppliers $(2,2)$. How do these results compare with 'desirable' collection 
states? Intelligence experts point to the importance of what is called primary information or knowledge (experts). This should form more than 80\% of information priority (Calof 1997). Yet, in this case, the dominant source was secondary (publications and libraries).

\subsection{Difficulties in accessing and using information}

What problems are South African exporters encountering when it comes to accessing international information? Respondents were asked to assess 10 different types of information barriers. The results are presented in Table 5. The dominant problem for virtually all respondents was that of language. Respondents had problems in that the information was only available in a foreign language. This was the only barrier that scored greater than $2(2,6)$. The second biggest problem was that of information interpretation.

Table 5 Difficulties in accessing and using information

\begin{tabular}{|l|c|}
\hline Difficulty & Average \\
\hline The information is only available in a foreign language & 2,6 \\
\hline The information is difficult to interpret & 1,9 \\
\hline Unknown whether the information can be found & 1,7 \\
\hline The information is expensive & 1,8 \\
\hline Unknown whether the information exists at all & 1,6 \\
\hline The modalities involved in obtaining the information are complicated & 1,6 \\
\hline The information is outdated & 1,6 \\
\hline The information is vague and non-pertinent & 1,6 \\
\hline Insufficient important is given to information in the enterprise & 1,6 \\
\hline It takes too much time to obtain the information & 1,5 \\
\hline
\end{tabular}

Scale: 1 = minor problem; 3 = major problem

The interpretation of information is the most important step in the research process. The identification of this as being a difficulty by the respondents suggests that analytical and language training may be important for South African exporters.

The identification of language as being the dominant barrier suggests poor information acquisition knowledge by respondents. The dominant language in South Africa is English and there is a plethora of international information readily available to executives in English. This study has identified several sources that may be consulted and should be considered when looking at international markets. Managers will also find an abundance of international trade information in electronic databases, including in the Internet that is readily available throughout South Africa. In a separate project, one of the authors of this article examined the export information requests made by South African and Canadian exporters to their respective embassies. In virtually all the cases, the information was readily available from the Internet - and in English. It is apparent then that the major problem may not be in the accessibility international information in English but a lack of understanding by South African exporters on how to get this information. Given that databases represent one of the more popular sources for information for South African exporters (2.0 average), it is reasonable to assume that there will be a positive predisposition to using the Internet for obtaining export-related information.

This is a useful place to start international information gathering efforts. Here are a few sites that address many of the information needs identified by respondents in this study: 
Montana State University (MSU) Centre for International Business Education and

Research (http://globaledge.msu.edu/ibrd/ibrd.asp). Recognized by the Cyber Sceptics guide as among the best sites for international business information, this site includes links to searchable trade show databases (one has over 30000 shows), trade leads from around the world, thousands of newspapers, and international trade treaties. It even has links to the numerous 'doing business in guides' including the CIA world fact-book, Overseas Investors Guides and Business Practices guides. For managers seeking assistance in the development of international marketing strategies, there is an online interactive business plan package complete with a tutor. This source contains information for virtually every category identified in this study as a high information need.

National Trade Data Bank (http://www.stat-usa.gov. With over 16000 international product studies and thousands of trade leads, the NTDB is a handy resource. Developed by the United States Department of Commerce, NTDB houses the vast numbers of foreign market studies commissioned by the US State Department. These include numerous product opportunity assessments, country guides, regional evaluations and global sectoral studies.

Strategis (http://strategis.ic.gc.ca). Developed by the Canadian Government, Strategis is a depository for Canadian government international and domestic studies. Under the category of industry insight reports, one will find insightful analysis of local (Canadian) and global opportunities, lists of contacts and suggested reading material. Strategis also houses a variety of NTDB reports.

Fuld and Company (http://www.fuld.com). Apart from being a well-respected CI firm, Fuld and Company also maintains a first-rate Web site. Under its reference section are pointers to sources of international information that the company has found invaluable.

There are also a host of search engines such as Yahoo (http://www.yahoo.com) that access a vast depository of country information. These are links directly to government and city information throughout the world. Most foreign governments maintain their own international and domestic studies on the Internet. The Fedworld Web site (http://www.fedworld.gov) is a government site that gives information on the US market for intelligence on Europe, the ECHO system (http://www.echo.lu) is a vast depository of European government documents.

\section{Conclusion}

The primary objective of this research was to establish how small and medium-sized South African firms gather exporting information. The results indicate the following:]

- Information related to market access conditions and market intelligence to identify buyers were the most important types of information requested by participants.

- Publications, customers, suppliers and trade partners were the most important sources of information for the study's respondents.

- Principle problems encountered in the information acquisition process lay with the information being difficult to interpret and problems in finding English language material.

Prior to making any recommendations, it should be pointed out that it is difficult to generalize the results of this study over the larger South African export community. These responses are those of one group, namely the members of the Pretoria Metropolitan Council. Firms associated with this council tend to be larger and more export experienced than the 
average South African exporter. However, if the more experienced exporters are having problems interpreting export information and finding it in English, then the problem may in fact be more serious for the average exporter. These results suggest the need to increase exporter awareness of information sources. Within Canada, the Federal Government has for the past five years been sponsoring a variety of training programmes that teach companies how to conduct market research and find competitive intelligence. Programmes range from a one-day Internet and intelligence course to multi-year certification programmes. Another important source of information is the embassy. Fuld (1995) identifies this as being one of the most important sources for international information. In a Canadian study of exporter information (Calof 1997), the Canadian Embassy was one of the top information sources for Canadian exporters. Further research is needed to identify why South African exporters are not making more use of their embassies.

\section{References}

Bodur, M. and Cavusgil, S.T. 1985. Export marketing research orientation of Turkish exporting firms. European Journal of Marketing 19(2):5-16.

Calof, J.L. 1993. The Mode choice and change decision making process and its impact on international performance. International Business Review 2(2):97-120.

Calof, J.L. 1997. So you want to go international? What information do you need and where will you get it? Competitive Intelligence Review (Winter):19-29.

Calof, J.L. and Viviers, W. 1995. Internationalization of small and medium sized South African enterprises. Journal of Small Business Management 33(4):71-79.

Czinkota, M.R. 1991. International information needs for US competitiveness. Business Horizons (Nov/Dec):86-91.

Czinkota, M.R. and Ricks, D. 1991. Export assistance: are we supporting the best programs? Columbia Journal of World Business (Summer):73-78.

Department of Trade and Industry. 1995. National Strategy for the Development and Promotion of Small Business in South Africa. Pretoria: Department of Trade and Industry.

Fuld, L. 1995. The new competitor intelligence. New York: John Wiley.

Hart, S.J., Webb, J.R. and Jones, M.V. 1994. Export marketing research and the effect of export experience in industrial SMEs. International Marketing Review 11(6):4-22.

Hoetker, G. 1996. Taking the competitive intelligence effort overseas: four special challenges. Competitive Intelligence Review (Summer):3-10.

Johanson, J. and Vahlne, J.E. 1978. The internationalization process of the firm: a model of knowledge development and increasing commitments. Journal of International Business Studies (Spring/Summer):23-32.

Leibold, M. 1984. The foreign orientation of management as a key variable in export commencement: Research Report 1. Bellville: University of Western Cape.

Mohamad, O., Zafar, A. and Honeycutt, J.E. 2001. The role of information in export 
marketing programs: an analysis by ownership structure. Multinational Business Review 9 (2):57-64.

Prescott, E. and Bhardwaj, G. 1995. Competitive intelligence practices: a survey. Competitive Intelligence Review (Summer):4-14.

Ricks, D. 1993. Big business blunders. Homewood: Dow-Jones Irwin.

Souchon, A.L. and Diamantopoulos, A. 1999. Export information acquisition modes: measure, development and validation. International Marketing Review 16(2):143-168.

\section{Disclaimer}

Articles published in SAJIM are the opinions of the authors and do not necessarily reflect the opinion of the Editor, Board, Publisher, Webmaster or the Rand Afrikaans University. The user hereby waives any claim he/she/they may have or acquire against the publisher, its suppliers, licensees and sub licensees and indemnifies all said persons from any claims, lawsuits, proceedings, costs, special, incidental, consequential or indirect damages, including damages for loss of profits, loss of business or downtime arising out of or relating to the user's use of the Website.

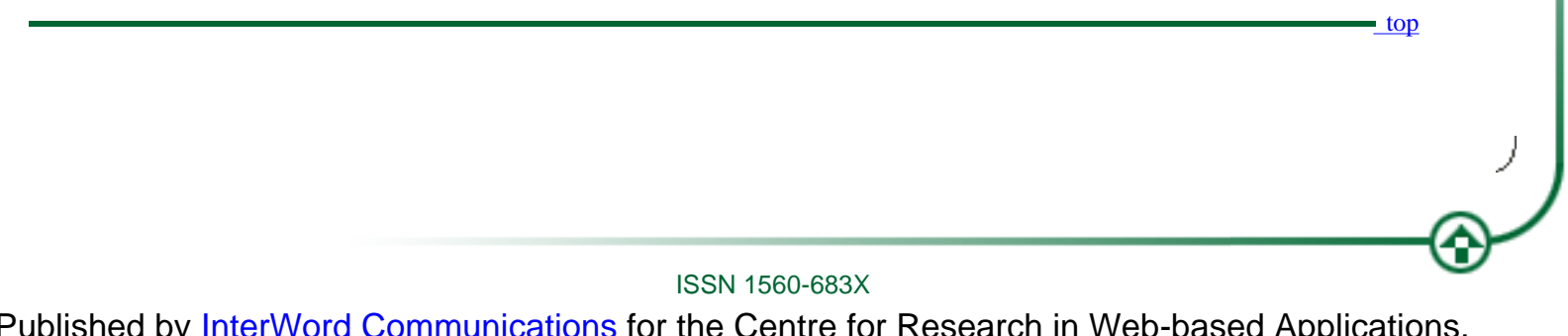

Published by InterWord Communications for the Centre for Research in Web-based Applications, Rand Afrikaans University 